\title{
LEPROSY CONTROL IN BALOVALE DISTRICT NORTHERN RHODESIA
}

\author{
J. T. Worsfold, M.B., Ch.B.
}

There are few published references to leprosy in Northern Rhodesia. In I932 Cochrane stated that " Northern Rhodesia had $I \%$ of lepers in parts " 1 and all later findings indicate that this figure was fairly accurate. In I939 Muir concluded that leprosy was much more common in Barotseland than elsewhere and singled out the Balovale District, then the Northern section of Barotseland, as the area which appeared to have the largest incidence. ${ }^{2}$ Ross Innes, in his I950 survey, did not include the western section of the Territory. $^{3}$ As a result of Muir's suggestion an effort has been made to establish a modern treatment centre at Chitokoloki on the Zambesi, which is situated centrally in the Balovale District. Experience here in the past six years may be of general interest.

The Balovale District is a sparsely populated district on the upper Zambesi. In an area of approx. I0,000 sq. miles there is a population of 4,I3I and a recent survey indicates that the incidence of leprosy does not exceed 9 per mille. A considerable proportion of the people and of the cases of leprosy are immigrants from neighbouring territories. The district is 50 miles from the line of rail and any European settled areas. The people are backward and the country undeveloped; there are now a considerable number 
of elementary schools but few adults can read or write. In the Lovale section of the country, on the west bank of the Zambesi, there are no roads nor European residents. These facts, and the sparsely settled nature of the country, influence the measures that can be taken to control leprosy. The villages of the people are scattered along the Zambesi and its smaller tributaries, and between the groups of villages are often many miles of sandy, light bush country. In any group of villages, at the most two or three patients with leprosy are to be found. This makes local segregation villages on the Nigerian model, enforced by enlightened public opinion, impracticable. There is no fear of leprosy and its victims are not obstructed but the majority of those affected now desire treatment for health's sake. House segregation, even if desired, is not likely to be effective under prevailing social conditions. Polygamy is widely practised and a wife with leprosy is not regarded differently from others. It is usual for these people to completely remove their villages periodically, as their fields become exhausted; they are not averse to leaving a district entirely and starting afresh elsewhere.

There are indications that amongst this group resistance is relatively high and the epidemic on the decline:

I. Few Children Show Clinical Signs of Leprosy. Out of I,509 school children examined in 1952 three were found with early indeterminate macules. From the whole area there are only two lepromatous children in the central settlement.

2. Low Proportion of Lepromas. For three years in succession (1949-50-5I) the lepromas amongst new cases admitted were $14 \%$.

3. Low Incidence of Lepra Fever. Usually only two or three cases are seen in any year.

4. Long Latent Period. A large number of those with infected near relatives do not develop the disease until middle or later life. There is good reason to assume that most of these have been in close or household contact with leprosy since childhood.

In a community such as this complete control should be possible in a reasonable time provided all cases can be brought under supervision. For the vast majority of adult Africans there is no employment available in the area and most are only too anxious to live in proximity to Europeans where they can find even a little remunerative employment and some measure of social security. This fact can be utilised to control the disease in the community. The answer probably lies in the provision of a 
sufficiently attractive yet disciplined centre where all cases and contacts can be investigated and provided for administratively. It is not sufficient to segregate all lepromas-this district is producing a considerable group of clinically indeterminate cases the pathology of which suggests some will become.lepromatous if not supervised and adequately treated. These cases are a danger as, before becoming frankly lepromatous, they are capable of infecting others.

A central settlement with permanent housing for 350 patients has been established at Chitokoloki. New cases reporting here are investigated and classified with special reference to origin, history, family contacts and children. Each new case has biopsy, clinical photograph, lepromin test, smears and routine check on concurrent disease done. After the above the case is assessed with a view to prognosis and disposal. A small number are out-patients $(20 \%)$.

Those retained in the leprosarium include:

I. Advanced, grossly positive lepromatous. (10\%).

These receive full rations, housing and comforts. Children are removed from them and if, for any reason, this is not possible, the children take prophylactic sulphone. If these advanced cases can be made contented under this regime their contacts are under close supervision.

2. Senile and grossly deformed patients requiring asylum. $(6 \%)$.

These are provided for on compassionate grounds and a separate section of the leprosarium is reserved for them where each has his or her own hut, bed and rations for life.

3. The largest section are the able-bodied, otherwise healthy, patients with good prognosis and requiring short-term treatment. These are, in the main, early tuberculoid and indeterminate cases and most can hope to be discharged within one to two years and thereafter submit to 3-monthly examination. The routine outside work of the settlement is done by this group and many of them learn a trade while here; the entire settlement has been built by patientlabour. Generally, their contacts require no supervision. This group includes about $20 \%$ of all patients.

\section{Nyamona Re-settlement Area :}

For all other patients (approx. $44 \%$ of the whole), relatively able-bodied and some requiring long-term treatment and supervision, a scheme of re-settlement villages has been established. The 
local Chief has set aside, exclusively for leprosy patients, an unlimited area of unoccupied ground 3 miles from the base hospital and here some eight large villages have been established. Any patient, or ex-patient, who so chooses may settle here for the rest of his life. Many of these people have only residual lesions and minor degrees of trophic loss; a few are lepromas who are stabilised on sulphone and responding well to treatment. Some are early cases who go because relatives are already settled there. Many, if not most, are people who could well return to their home villages but for political and other reasons prefer the social security of living under the eye of a European.

These villages have become very popular. They have a good water supply from wells, the soil is relatively good and they have already brought under cultivation a huge area of virgin land. For food and housing the villagers are completely self-supporting. They get the same medical attention and treatment as the patients in the central leprosarium and there is no tendency for them to leave the villages as they own the houses and gardens. Any case of acute illness is admitted to the base hospital.

This experiment which is proving so practicable is providing a unique opportunity for observing the long-term results of sulphone treatment. At present the emphasis is on accurate record keeping as we are gathering in this re-settlement area, with no charge on public funds, a large number of former leprosy patients who have elected to remain under our observation and care for the remainder of their lives.

\section{REFERENCES.}

1. R. G. Cochrane, "Leprosy in the Rhodesias," Lep. Rev. 3 (1932), 25.

2. E. MuiR, "Leprosy in Northern Rhodesia," Lep. Rev. Vol. XI, No. 1, 1940.

3. J. Ross InNes, "Leprosy Survey, Northern Rhodesia," 3rd June 1950. 